\title{
IAMJ
}

INTERNATIONAL

AYURVEDIC

MEDICAL JOURNAL

\section{A COMPARATIVE CLINICAL STUDY TO EVALUATE THE EFFECT OF VAMA-NAKARMA WITH MADANAPHALA VARTI AND MADANAPHALA AVALEHYA YOGA IN POLYCYSTIC OVARIAN SYNDROME (PCOS)}

\author{
Shwetambika ${ }^{1}$, Ananta. S. Desai ${ }^{2}$, Shaila Borannavar ${ }^{3}$ \\ ${ }^{1}$ PG Scholar, ${ }^{2}$ Guide, Professor \& HOD, ${ }^{3}$ Associate Professor \\ Dept of PG Sstudies in Panchakarma, GAMC, Bangalore-560009, Karnataka, India
}

Corresponding Author: shweta93bs@gmail.com

https://doi.org/10.46607/iamj1009102021

(Published Online: October 2021)

Open Access

(C) International Ayurvedic Medical Journal, India 2021

Article Received: 01/10//2021 - Peer Reviewed: 09/10/2021 - Accepted for Publication: 11/10/2021

Check for updates

\begin{abstract}
Polycystic ovarian syndrome is one of the most common endocrine disorders affecting women in their reproductive age group and the most common cause of anovulatory infertility. It is characterized by the presence of menstrual irregularities, infertility, hirsutism, acne, hair loss, insulin resistance, hyperandrogenemia, central obesity and dyslipidemia with a higher risk of developing Diabetes mellitus, endometrial hyperplasia and cardiovascular diseases. It is important to treat these patients early to help them, deal with emotional stress caused by hirsutism, infertility, obesity that is often overlooked with PCOS. So early diagnosis and proper management can help society to control PCOS so that women can live a healthy, active life and avoid long term complications such as metabolic syndrome and cardiovascular disease. The present study has been done to evaluate the effect of Vamana karma with Madanapala Varti and Madanaphala Avalehya yoga in PCOS. Methodology: 40 patients suffering from PCOS. Group A-Vamana karma with MadanaphalaVarti Yoga, Group B - Vamana karma with MadanaphalaAvalehyaYoga. Result And Conclusion. The test shows that the treatment is not significant in Group A when compared to Group B. Group A overall result is $28.87 \%$ and Group B overall result is $32.37 \%$. Both groups showed mild improvement in features of PCOS both clinically and statistically.
\end{abstract}


Keywords: PCOS, Artavakshaya, Vamankarma, Madanaphalavarti and MadanaphalaAvalehya yoga.

\section{INTRODUCTION}

Reproductive phase of life in a woman plays a major role in creating a sense of wellness and identity in her social life. Conception and childbearing are influenced by and depend on many factors. One such factor is regular menstruation. Vamanakarmais the prime shodhana therapy told for all the kaphajavikara. ${ }^{1}$ It helps in the elimination of aggravated kapha at its own site, an association of kapha with pitta or the condition in which pitta or vata invades the site of kapha. ${ }^{2}$ PCOS can be correlated with Artavakshayain Ayurveda, which has been described by Acharya Susruta along with the clinical features of kshaya of all the doshas, dhatus and upadhatus. ${ }^{3}$ Thus it appears to be a description of deficiency of artava which is a upadhatu of rasa. According to susrutaartavais a predominant of agnimahabhuta. ${ }^{4}$ Vamana removes the soumyaguna resulting in a relative increase in agneyadhatu, consequently, arta$v a$ also increases. ${ }^{5}$ In the present era, erratic lifestyle and diet, increased stress, strain and restlessness have resultantly expanded the spread of hormonal imbalance and menstrual disorders. PCOS is the most frequent endocrine disorder affecting $4-12 \%$ of all women of childbearing age. ${ }^{6}$ PCOS was originally described in 1935 by Stein and Leventhal as a syndrome manifested by amenorrhea, hirsutism and obesity associated with the enlarged polycystic ovaries. ${ }^{7}$ As declared by WHO the prevalence of PCOS, in the general population has been estimated to be $5-10 \%$ in reproductive-age women. Recent findings from developing countries like India and China have similar prevalence rates. ${ }^{8}$ In the past, PCOS has been looked at primarily as an endocrine disorder, but recent studies show PCOS is a metabolic, hormonal and psychosocial disorder that impacts a patient's quality of life. It is important to treat these patients early to help them, deal with emotional stress caused by hirsutism, infertility, obesity that is often overlooked with PCOS. So early diagnosis and proper management can help society to control PCOS so that women can live a healthy, active life and avoid long term complications such as metabolic syndrome and cardiovascular disease.

Madanaphala is the best drug for inducing vamana, as it is very safe to use for emesis because it does not cause any complications. ${ }^{9}$

Among various formulations mentioned by Acharya Charaka, for vamana karma, very few yogas are used in practice, so Varti and Aavalehyayogas are taken to know its effect, palatability, ease of the procedure and for further clinical practice.

\section{SAMPRAPTI GHATAKAS:}

- Dosha-Vata-ApanaVata, SamanaVata, vyana

- VataPitta-Pachaka

- PittaKapha- KledakaKapha

- Dhatu-Rasa, Rakta, Meda

- Upadhatu-Artava

- Agni-JatarAgni, DhatavAgni

- Srotas- Rasavaha, Artavahasrotas, Medovaha

- Srotodusti-Sanga

- Udbhvastana-Amapakwashaya

- Adhisthana- Garbhasaya

- Sancharasthana-Sarvashareera

- Vyaktasthana- Yoni, Garbhasay

MATERIALS AND METHODS

\section{Materials required}
1) Vamana peeta.
2) Abhyanga droni.
3) Bashpa Swedana yantra
4) Stove
5) Big and small vessels
6) Measuring glass, Jar and Buckets
7) Towel 


\section{METHODOLOGY}

Table 1: Shows the Drugs required for the study

\begin{tabular}{|l|l|l|}
\hline Purva karma & Pradhana karma: & Paschat karma: \\
\hline Trikatu Churna & Ksheera & Haridra dhuma Varti. \\
\hline Murchita Grita & MadanaphalaAvalehya Yoga & \\
\hline Murchita Tila taila. & Madanaphala Varti Yoga & \\
\hline & Yashtimadhu Quatha & \\
\hline & Saindhava jala & \\
\hline
\end{tabular}

\section{PREPARATION OF YOGA:}

Table 2: Shows the Ingredients required for the yogas

\section{Madanaphala Avalehya yoga}

Guduchi Quatha Churna

Madanaphala pippali Churna

Khandasharkara

Water

Honey

\section{Madanaphala Varti yoga}

Kutaja Quatha Churna

Madanaphala pippali Churna

Water

Honey

\section{Method of preparation of}

a) Madanaphala Avalehya Yoga

Guduchi Quatha Churna + 4 liters of water boiled till it reduced to $500 \mathrm{ml}$<smiles>C1CCC1</smiles>

Khanda sharkara added \& made to dissolve and strained to remove the physical impurities

This solution is heated over moderate temperature to obtain tanupaka<smiles>C1CCC1</smiles>

When the paka becomes thready consistent (tantutvam) \& sinks in water without getting dissolved (apsu majjati)

it should be removed from the fire<smiles>C1CCC1</smiles>

To this fine powder of Madanaphala pippali Churna is added in small quantities \& stirred continuously and vigorously to form a homogenous mixture.<smiles>C1CCCCC1</smiles>

Honey is added when the preparation is cool and mixed well

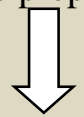

Madana phala Avalehya

(After complete cooling, it must be packed in a dry, airtight, wide-mouthed good quality container).

\section{b) Madanaphala Avalehya Yoga}

Kutaja Quatha Churna +8 litres of water boiled till it reduced to $500 \mathrm{ml}$ and it is made more concentrated at last madana phala pippali Churna is added and made into Varti form. 


\section{METHODOLOGY}

\section{- SAMPLE SOURCE:}

Subjects suffering from PCOS are selected from the Panchakarma Postgraduate OPD and IPD of Government Ayurveda Medical College Hospital Bengaluru

\section{METHODS OF COLLECTION OF DATA}

A minimum of 40 subjects suffering from PCOS fulfilling the diagnostic criteria was registered for the study. irrespective of religion, race, and socioeconomical status from the OPD, IPD and special camps conducted at Sri Jayachamarajendra Institute of Indian Medicine Hospital, Bengaluru-09. The Subjects were assigned randomly into two groups viz., group A and group B. Each group consisting of a minimum of 20 Subjects.

\section{DIAGNOSTIC CRITERIA}

Subjects fulfilling the revised Rotterdam criteria (2003) require the presence of two of the following:

- Oligomenorrhea-or anovulation,

- Clinical and/or Biochemical signs of Hyperandrogenism.

- Polycystic ovaries

\section{INCLUSION CRITERIA}

- Subjects with the age of 18-40 yrs.

- Subjects fulfilling the diagnostic criteria of PCOS.

- Subjects fit for Vamana.

\section{EXCLUSION CRITERIA}

- Subjects diagnosed with hypo/hyperthyroidism, Blooddyscriasis and Anaemia.

Pregnant and lactating women.

\section{STUDY DESIGN}

Table 3: Showing the treatment plan

\begin{tabular}{|c|c|c|}
\hline & GROUP A & GROUP B \\
\hline POORVAKARMA & $\begin{array}{l}\text { Deepana, Pachana with trikatuChurna } 1 / 2 \text { tsf bd } \\
\text { before food with ushnajala till niramaavastha } \\
\text { Snehapana with murchitaGrita in arohanakrama } \\
\text { 3-7 days till the SamyaksnigdhaLakshana. } \\
\text { SarvangaAbhyanga with moorchitatilataila } \\
\text { fallowed by bhashpaSweda } \\
\text { Kaphakaraahara (for doshautkleshana) }\end{array}$ & $\begin{array}{l}\text { Deepana, Pachana with trikatuChurna1/2tsf bd } \\
\text { before food with ushnajala till niramaavastha } \\
\text { Snehapana with murchitaGrita in arohanakrama } \\
\text { 3-7 days till the SamyaksnigdhaLakshana. } \\
\text { SarvangaAbhyanga with moorchitatilataila } \\
\text { fallowed by bhashpaSweda } \\
\text { Kaphakaraahara (for doshautkleshana) }\end{array}$ \\
\hline $\begin{array}{l}\text { PRADHANA } \\
\text { KARMA }\end{array}$ & $\begin{array}{l}\text { Vamana karma with MadanaphalaVarti Yoga } \\
\text { Mrudu koshta-8gm } \\
\text { Madhyama koshta-10gm } \\
\text { Krura koshta-12gm }\end{array}$ & $\begin{array}{l}\text { Vamana karma with MadanaphalaAvalehya Yo- } \\
\text { ga } \\
\text { Mrudu koshta- } 25 \mathrm{gm} \\
\text { Madhyama koshta }-30 \mathrm{gm} \\
\text { Krura koshta-35gm }\end{array}$ \\
\hline $\begin{array}{l}\text { PASCHAT KAR- } \\
\text { MA }\end{array}$ & $\begin{array}{l}\text { Haridradhoomapana } \\
\text { Samsarjanakrama depending upon the shud- } \\
\text { dhiLakshanas. }\end{array}$ & $\begin{array}{l}\text { Haridradhoomapana } \\
\text { Samsarjanakrama depending upon the shud- } \\
\text { dhiLakshanas. }\end{array}$ \\
\hline
\end{tabular}

Duration of the study:

$\checkmark$ Pachana and Deepana for 2-3 days. (Till Niramavastha)

$\checkmark$ Snehapana for 3-5 days. (Till the appearance of Samyak snigdha Lakshana)

$\checkmark$ Abhyanga and Swedana for -1day.

$\checkmark$ Vamana karma-1day

$\checkmark$ Samsarjana karma 2-5 days (Based on shuddhis)

- The total duration of the study is 15 days.
- Follow up- 60th days. SUBJECTIVE PARAMETER

- Duration of the menstrual cycle.

- Amount of bleeding.

PARAMETERS TO ASSESS VAMANA

- Laingikishuddhi

OBJECTIVE PARAMETER

- USG

- BMI 
OBJECTIVE PARAMETERS TO ASSESS VAMANA

- Vegikishuddhi

- Manikishuddhi
- Antikishuddhi

ASSESSMENT OF TOTAL EFFECT OF THERAPY

Table 4: Comparative results of Group-A and Group-B on Objective Parameter

\begin{tabular}{|l|l|l|l|l|l|l|}
\hline Signs and Symptoms & Group A (Mean Score) & Group B (Mean Score) & S.D( \pm ) & S.E $( \pm)$ & T Value & P-Value \\
\hline Interval between cycles & 2.03 & 2.18 & 0.651 & 0.149 & 0.89 & $>0.05$ \\
\hline Duration of bleeding & 3.50 & 3.40 & 0.308 & 0.071 & 0.62 & $>0.05$ \\
\hline Amount of menstrual flow & 2.60 & 2.88 & 1.094 & 0.251 & 1.40 & $>0.05$ \\
\hline Amount of menstrual flow & 2.60 & 2.88 & 1.094 & 0.251 & 1.40 & $>0.05$ \\
\hline BMI & 26.31 & 25.35 & 2.844 & 0.653 & 1.42 & $>0.05$ \\
\hline USG & 2.75 & 2.75 & 0.725 & 0.166 & 0.00 & $>0.05$ \\
\hline
\end{tabular}

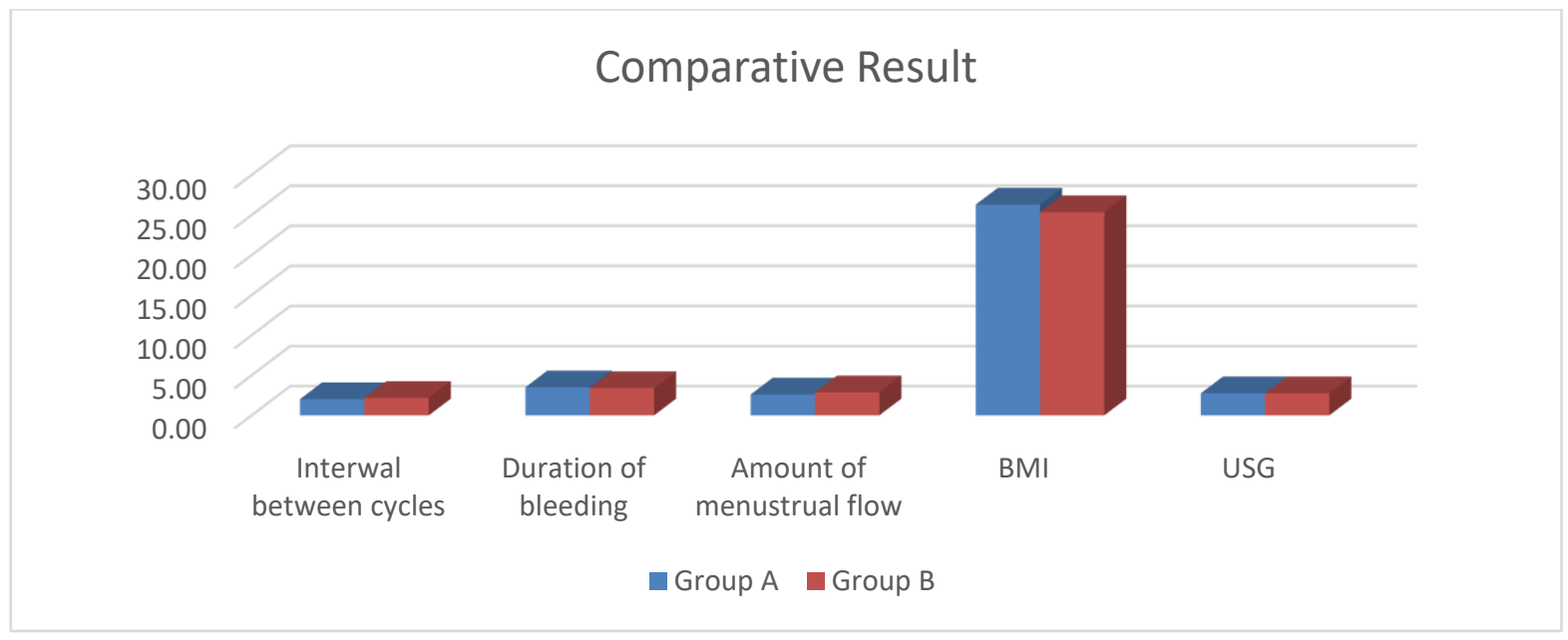

Table 5: Comparative results of Group A and Group B

\begin{tabular}{|l|l|l|l|l|l|}
\hline Group A & Group B & Mean Difference & SE $( \pm)$ & T value & P-value \\
\hline 28.87 & 32.37 & 3.50 & 2.80 & 1.19 & $>0.05$ \\
\hline
\end{tabular}

Comparative analysis of the overall effect of the treatments in both groups was done statistically with an unpaired t-test. The test shows that the treatment is not significant in Group A when compared to Group B. Group A overall result is $28.87 \%$ and Group B overall result is $32.37 \%$.

Table 6: The overall effect on Group-A

\begin{tabular}{|l|l|l|}
\hline EFFECT OF TREATMENT IN GROUP - A & No of Subjects \\
\hline Class & Grading & 14 \\
\hline $51 \%-50 \%$ & Mild & 0 \\
\hline $76 \%-100 \%$ & Moderate & 0 \\
\hline
\end{tabular}




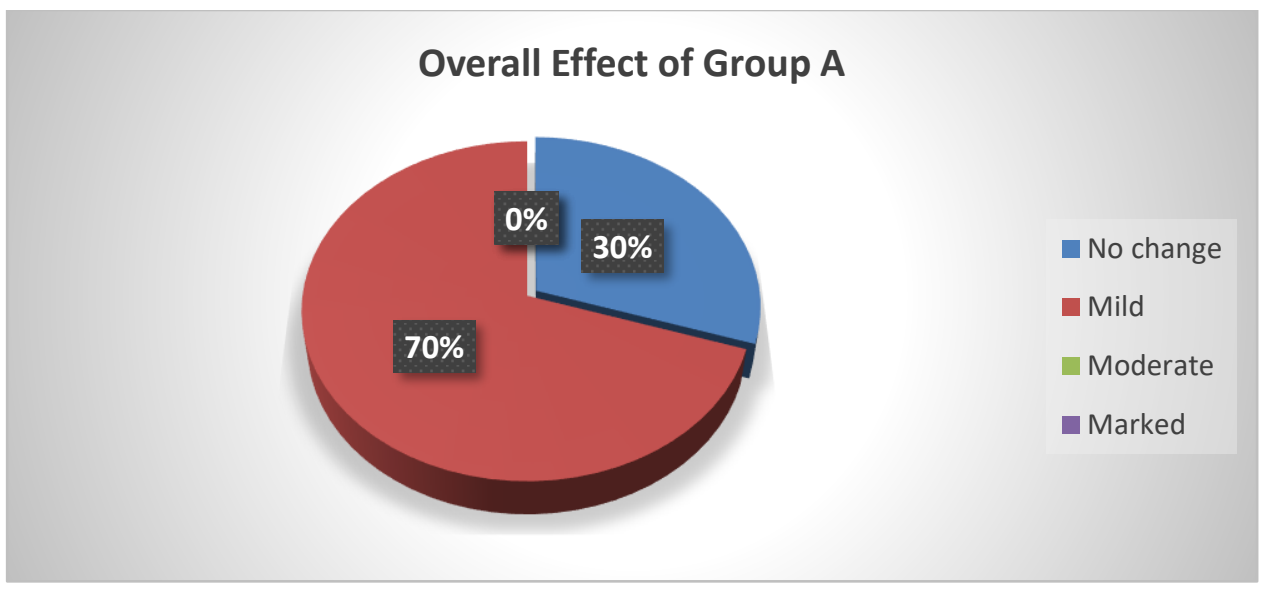

Table 7: Overall effect of Group-B

EFFECT OF TREATMENT IN GROUP - B

\begin{tabular}{|l|l|l|}
\hline Class & Grading & No of Subjects \\
\hline $0-25 \%$ & No change & 4 \\
\hline $26 \%-50 \%$ & Mild & 16 \\
\hline $51 \%-75 \%$ & Moderate & 0 \\
\hline $76 \%-100 \%$ & Marked & 0 \\
\hline
\end{tabular}

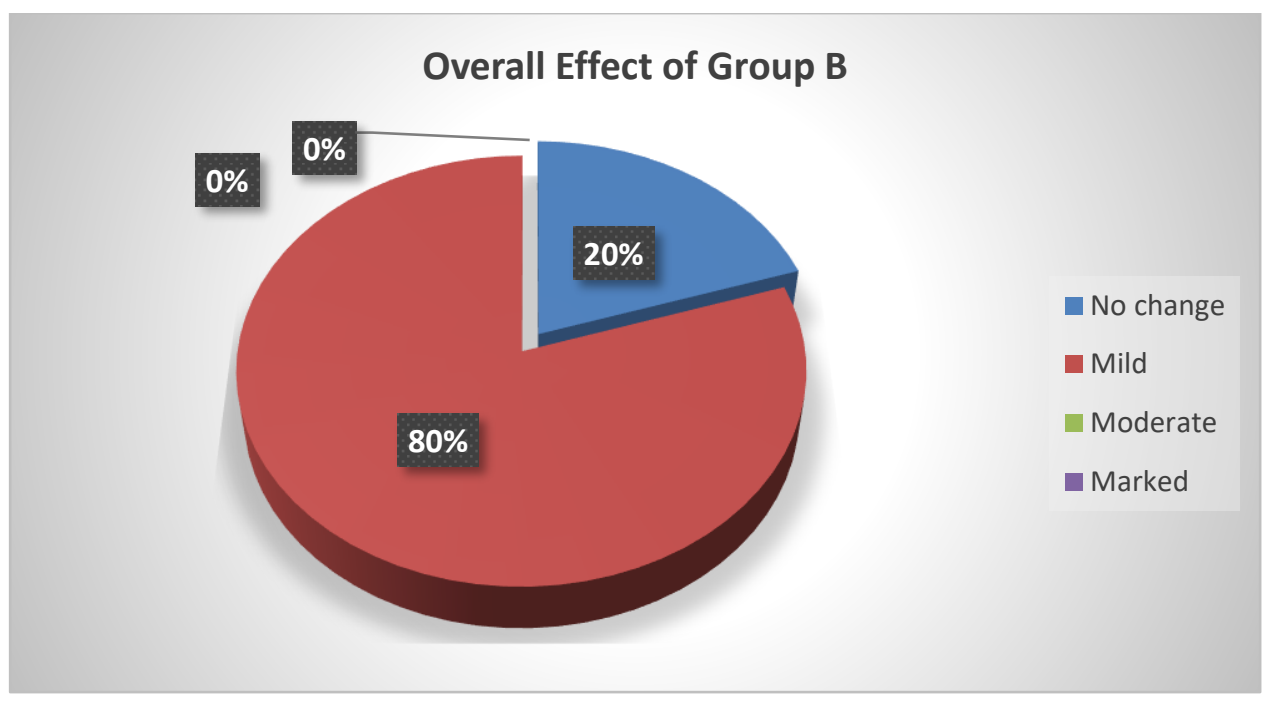

\section{DISCUSSION}

Vamana is a medicated emesis therapy, which removes morbid Kapha collected in the body. These interventions are done only when there is a high Kapha imbalance occurs. Systematic daily treatment starting from Pachana to Swedana involves loosening and mobilizing the morbid Dosha to eliminate them. Vamana is the purificatory procedure to eliminate, expel vitiated Dosha through the gastro- intestinal tract particularly the augmented Kapha. By this treatment, vitiated Kapha Dosha from Sahakha to Koshta and Eliminated through the mouth.

Effect of Vamanakarma on the entire body system can be explained by the concept of regulation of homeostasis by nervous system \& endocrine system: A hypothetical approach There is an imbalance of Dosha in the diseased condition which means normal homeostasis (internal milieu) is disturbed. 
Deepana, Pachana: Enzymatic system or metabolic activity of the body is activated at intracellular \& circulatory levels, which are under the control centres in the brain. Mild action on the local autocrine, paracrine gland may be noted. Thus, the body is made to face further disturbance

Snehapana: Closely monitored \& systematically controlled physiological, pathological changes are artificially made through the oral administration of Snehapana to disturb homeostasis for which the body responds positively or negatively through a feedback mechanism system. Thus, systems are activated or suppressed, bringing changes at a molecular level, ionic level, cellular level, tissue level etc. Anabolic, catabolic process (like breaking down, rearranging, remodelling, reconstructing in chemical constituent, ionic bonds etc) in the body is activated or suppressed through various physiochemical principles involved in the body.

Swedana: adjustment to the changes caused by the external environment to that of the internal environment is the main concern of the homeostatic system. By subjecting the body in a programmed manner to Pravara shuddhi \& Swedana further disturbance is made in homeostasis. Swedana increases microcirculation - again rearrangement of bodily chemicals---inducing stress----feedback mechanism activated---separation of toxin----movements of this from extracellular to intercellular space creating a lot of changes in biochemical constituents of the body.

Vishrama Kala: By following this, a time is given to the system to come back in a natural way in the process of conversion, separation, formation reunion etc of molecules. It is for one day in Vamana may be only such physio chemical molecule can take part. Providing Kaphakara Ahara may be to increase such physiochemical activities.

Vamana karma: An intervention to make the body come back to the normal state of homeostasis, which is strictly observed by Maniki, Lingiki, Antiki Lakshana's.

Samsarjana karma: Body is made fit again or for faster systematic rejuvenation is achieved in a natural way allowing all the system to improve in its own way.

In practice, it has come to our observation that in the Pravara shuddhi of Vamana there is a maximum weight loss of $8 \mathrm{~kg}$ with a good clinical response which indicates it is Apatarpana chikitsa. Each \& every step from Deepana to Samsarjana karma is equally important in getting good results.

\section{Mode of action of Vamana Aushadhi:}

The Vamana Aushdha is comprised of qualities like Ushna, Tikshna, Sukshma, Vyavayi, Vikasi. And formed with a predominance of Agni and Vayu Mahabhuta. But the main action is attained by the Urdhwabhagahara Prabhava possessed by these drugs. ${ }^{10}$

- The drugs due to their Veerya will reach $\mathrm{Hri}$ daya and Dhamani thereby reaches Sthula and anusrotas of the body.

- The vyavayi Guna of the drug will help in the quick absorption and movement of the drug.

- Vikasi Guna will help in breaking the binding of Dosha and Dushya.

- Due to Ushna Guna drug will cause Vishyandana

- $\quad$ Tikshna Guna causes Chedana of Doshas.

- The Sukshma Guna helps to reach minutes channels

- Agni and Vayu Mahabhuta because of its qualities like Laghuta and tendency to move upwards will help in bringing Vamaka effects.

More importantly, Prabhava of the drug is especially responsible for bringing about the Vamana action. While describing the act of Vamana, Charaka has used the "Udana Pranunno" on which Chakrapani comments that Vamana drugs lead to upward direction due to Udanavayu \& has the prime role in conducting the whole Vamana process as it occurs in its site. Charaka narrates the site of Udanavayu as Nabhi, Urah \& Kantha. Vagbhata also supports his view \& adds new sites like 'Nasa' and plays a role in activating Dhi, Mana, continuous changes of Fight or Flight emotions, Thus, Udana Vayu helps the Vamana drugs to remove the extracted matter through an 
exhaustive process of Vamana which indicates involvement of nervous system.

Dhamani is the channel that carries some constituents with them.

Definition- "Dhamanat dhamanyah" means which pulsates. Thus, it is the structure resembling an artery. Chakrapani also comments that it provides nourishment to paramanus. So, in the Vamana process, Dhamani is the medium through which Vamana drugs reach the cellular level for their purpose. He remarks that Vamaka drugs remain there themselves $\&$ pass the impulses towards several areas throughout the body through Dhamani. This distinctly points to the conduction of impulses through the means of nerves, Thus the act of Vamana proceeds through both the systems i.e circulatory \& nervous systems.

Hrudaya: The drugs, due to their "Swaveerya" reach Hrudaya from where they spread to all over the body. To reach the micro-level through the body in a very short time, chief systems are circulatory\& nervous. As it said that Vamana drugs move into Dhamani after passing from Hrudaya, one can say that here the word "Hrudaya" may have both the meanings, showing the involvement of both the vital \& chief organs i.e Heart \& Brain.

- Akantapana of milk causes starching of the stomach, initiating stretch receptor to send the neurological signal through the vagus nerve to vomit centres in the brain, after taking

Madanaphala Yoga chemoreceptor detects changes in ph of the stomach content \& send the signal to the brain, thus initiating an act of Vamana without absorption of the drug.

The probable mode of action of Vamana with Madanaphala Avalehya and Varti Yoga in PCOS is mainly Dosha pratyanika

- By doing Deepana, Pachana, Snehapana, Swedana as Purvakarma in a systematic way helps in the separation, mobilization and liquefication of morbid Dosha \& altered biochemical constituents).

- Sex hormones namely Estrogen, Androgen are formed only by cholesterol hence intake of Snehapa$n a$ may help in their formation
- Snehapana increases Agni this may increase ovarian growth factors i.e IGF System etc discussed earlier Make estrogen, FSH, etc receptors to activate

- Vamanakarma \& Samsarjana karma brings back Doshik imbalance. Maybe corrects at the level of insulin hormone, androgen hormone, helping developed follicle to rupture. Thus, practised line of treatment of modern medicine weight reduction, decreasing in insulin-like growth factor, harmonizing the hormone can be achieved by Vamanakarma.

From available data in humans, it is likely that the IGF system, increased IGF -2 decreased IGFBP-2 Increased IGFBP-4 Protease is "turned on at the time of dominant follicle selection ${ }^{11}$. Ayurveda identifies the dominance of Kapha Dosha-Soumya Dhatu as an important causative factor in Artavakshaya \& removal of this is achieved by Vamana Karma to maintain Agneya tatva in the normal condition a possible approach correcting at the level.

\section{CONCLUSION}

Shedding light on the symptomatology of the disease based on Ayurvedic fundamentals it becomes evident that kaphadosha is the chief culprit along with vitiation of vata and pitta dosha. This trihumoral vitiation is accompanied by vitiation of Agni which, in turn, leads to Rasa, Rakta, and meda dhatu, Artava Upadhatu dushti predominantly. The majority of Kapha Vata Prakruti individuals were seen in the study, which may be because of the proximity of these Doshas with the disease entity. The disease was mainly found in patients having irregular diets, sleep and stressful sedentary lifestyle. Hence Repeated Vamana followed by Anulomana would be more effective in its management. The Time of initiation of Vegas was within 15-20 mins with Madanaphala Avalehya Yoga and 30-35 mins with Madanaphala Varti Yoga. Even in some cases, the Pittanta was not seen practically but on checking the ph of vomitus at the end of the procedure, $\mathrm{Ph}$ was 9(alkaline) and it may be considered as pittanta as $\mathrm{Ph}$ of bile ranges from 8.5-9. Better results were observed in the regularization of the menstrual cycle, normalization of duration and amount of bleeding, reduction in body weight, 
acne in both the group, except the reduction of the size of the cyst in USG. 60 days is not a sufficient duration to find changes in USG.

Comparative analysis of the overall effect of the treatments in both the groups showed that the treatment is less significant in Group A when compared to Group B. Group A overall result is $28.87 \%$ and Group B overall result is $32.37 \%$. Hence Alternate Hypothesis was proven.

\section{REFERENCES}

1. Agnivesha. Charaka Samhita, annotatedbyCharaka and redacted by Dridhabala with the Ayurveda dipika commentary of chakrapanidatta, edited by YadavajiTrikamji Acharya. sutrasthana11/48-49 pp -77.

2. Agnivesha. Charaka Samhita, annotated by Charaka and redacted by Dridhabala with the ayurvedadipika commentary of chakrapanidatta, edited by YadavajiTrikamji Acharya. Kalpasthanapublished by Chaukambha Sanskrit samsthan, Varanasi, 1/11.

3. Prof. Premavati Tiwari, Ayuvediyaprasutitantraevamstriroga part 2, published by Chaukambhaorientalia, Varanasi, reprint 2000, Pg. no 163.

4. Sushruta, Sushruta Samhita volume 1, edited with Ayurveda tatvasandeepika by Kavirajaambika data shastri, samsthan, Varanasi, reprint 2015, Sutrasthan 15/16 pg. no-77 published by Chaukambha Sanskrit.

5. Prof. Premavati Tiwari, Ayuvediyaprasutitantraevamstriroga part 2, published by Chaukambhaorientalia, Varanasi, reprint 2000, pg. no 167.

6. William gynaecology, Barbara L. Hoffman, Johno. Sehorge, Joseph I Schaffer, Lisa M Halvorron, Karen D Bradshaw, F. Gary Cunningham. McGraw Hill Dallas 2nd. JEFFCOTS Principles of gynaecology, revised and updated by pratapkumar, MD narendra Malhotra. Jaypeebrothers publications, $7^{\text {th }}$ international edition pg. no. 384 Pp 964.

7. DC Datta, textbook of gynaecology, edited by hiralalkonar published by Jaypee brothers' medical publishers, pg. no 459.

8. Allahbadia, GN, Merchant R (2008) Polycystic ovary syndrome in the Indian subcontinent. Seminars in Reproductive Medicine 26(1):22-34.

9. AgniveshacharakasamhitaEnglish translation and critical position based on Chakrapanidatta's Ayurveda Deepika by DrRamkaransharma and Vaidya Bhagavan das volume 6 published by Chaukambha Sanskrit series office, Varanasi reprint 2013 kalpasthana 1/1314.

10. AgniveshacharakasamhitaEnglish translation and critical position based on Chakrapanidatta's Ayurveda Deepika by DrRamkaransharma and Vaidya Bhagavan das volume 6 published by Chaukambha Sanskrit series office, Varanasi reprint 2013 kalpasthana 1/05 PP 3.

11. https://www.ayurtimes.com 27/5/20: 3 pm

\section{Source of Support: Nil Conflict of Interest: None Declared}

How to cite this URL: Shwetambika et al: A Comparative Clinical Study To Evaluate The Effect Of Vama-Nakarma With Madanaphala Varti And Madanaphala Avale-hya Yoga In Polycystic Ovarian Syndrome (PCOS). International Ayurvedic Medical Journal \{online\} 2021 \{cited October 2021\} Available from: http://www.iamj.in/posts/images/upload/2353 2361.pdf 